SPECIAL ISSUE ON BASIC NURSING CARE

\title{
Nurses' Scope of Practice and the Implication for Quality Nursing Care
}

\author{
J.C. (Irene) Lubbe, PhD, RN, RM ${ }^{1}$ \& Lizeth Roets, PhD, RN, RM² \\ 1 Tau Lambda-at-Large, Senior Lecturer, Health Studies, University of South Africa (Unisa), South Africa \\ 2 Tau Lambda-at-Large, Associate Professor, Health Studies, University of South Africa (Unisa), South Africa
}

\section{Key words}

Risk assessment, basic nursing care,

Waterlow $^{\mathrm{TM}}$ scale, scope of practice

\section{Correspondence}

Dr. J.C. (Irene) Lubbe, PO Box 392, University of

South Africa (Unisa), 0003, South Africa.

E-mail: Lubbejc1@unisa.ac.za

Accepted: October 28, 2013

doi: $10.1111 /$ jnu. 12058

\begin{abstract}
Purpose: This article provides an overview of the implications for patients' health status and care needs when assessments are performed by nurses not licensed or competent to perform this task. The Waterlow ${ }^{\mathrm{TM}}$ scale (Judy Waterlow, The Nook, Stroke Road, Henlade, TAUNTON, TA3 5LX) scenario is used as a practice example to illustrate this case.

Organizational Construct: The international nursing regulatory bodies, in South Africa called the South African Nursing Council, set the scope of practice wherein nurses are allowed to practice. Different categories of nurses are allowed to practice according to specified competencies, in alignment with their scope of practice.

Methods: A retrospective quantitative study was utilized. A checklist was used to perform an audit on a random sample of 157 out of an accessible population of 849 patient files. Data were gathered in May 2012, and the analysis was done using frequencies and percentages for categorical data. Reliability and validity were ensured, and all ethical principles were adhered to.

Findings: Eighty percent of risk assessments were performed by nurses not licensed or enrolled to perform this task unsupervised. Areas such as tissue malnutrition, neurological deficits, and medication were inaccurately scored, resulting in $50 \%$ of the Waterlow ${ }^{\mathrm{TM}}$ risk-assessment scales, as an example, being incorrectly interpreted. This has implications for quality nursing care and might put the patient and the institution at risk.

Conclusions: Lower-category nurses and student nurses should be allowed to perform only tasks within their scope of practice for which they are licensed or enrolled. Nurses with limited formal theoretical training are not adequately prepared to perform tasks unsupervised, even in the current global nursing shortage scenario.

Clinical Relevance: To optimize and ensure safe and quality patient care, risk assessments should be done by a registered professional nurse, who will then coordinate the nursing care of the patient with the assistance of the lower category of nurses.
\end{abstract}

The nursing profession is in a crisis as the shortage of nurses escalates each year (George, Quinlan, Reardon, \& Aguilera, 2012). However, the general public expects to be cared for by competent nurses to deliver optimal care and in so doing ensure their safety and recovery from illness (Fero, Witsberger, Wesmiller, Zullo, \& Hoffman,
2008). The regulatory bodies provide a scope of practice for each category of nurse. The dire shortage may contribute to nurses performing tasks that they are not competent and licensed or registered to perform. The health and safety of patients can be threatened, however, when nurses are permitted to perform patient care duties that 
Table 1. Educational Institutions Versus Categories of Nurses Trained in South Africa

\begin{tabular}{|c|c|c|c|c|}
\hline & Private NEI & Nursing college & University of technology & University \\
\hline $\begin{array}{l}\text { Academic } \\
\text { qualification }\end{array}$ & Diploma & Diploma & Degree & Degree \\
\hline \multirow[t]{2}{*}{$\begin{array}{l}\text { Professional } \\
\text { qualification }\end{array}$} & $\begin{array}{l}\text { Registered professional general } \\
\text { nurse (RPN) (R.683) }\end{array}$ & $\begin{array}{l}\text { Registered professional nurse } \\
\text { (general, psychiatry, } \\
\text { community and midwife) } \\
\text { (R.425) }\end{array}$ & $\begin{array}{l}\text { Registered professional nurse } \\
\text { (general, psychiatry, } \\
\text { community and midwife) } \\
\text { (R.425) }\end{array}$ & $\begin{array}{l}\text { Registered professional nurse } \\
\text { (general, psychiatry, } \\
\text { community and midwife) } \\
\text { (R.425) }\end{array}$ \\
\hline & & NQF & NQF & NQF \\
\hline First year & $\begin{array}{l}\text { Enrolled nursing auxiliary (ENA) } \\
\text { (R.2176) NQF } 4\end{array}$ & $\begin{array}{l}\text { Practice as a first-year student } \\
\text { NQF }\end{array}$ & $\begin{array}{l}\text { Practice as a first-year student } \\
\text { NQF }\end{array}$ & $\begin{array}{l}\text { Practice as a first-year student } \\
\text { NQF }\end{array}$ \\
\hline \multirow[t]{2}{*}{ Second year } & $\begin{array}{l}\text { Enrolled nurse (EN) (R.2175) } \\
\quad \text { NQF } 5\end{array}$ & $\begin{array}{l}\text { Practice as a second-year } \\
\text { student }\end{array}$ & Practice as a second-year student & $\begin{array}{l}\text { Practice as a second-year } \\
\text { student }\end{array}$ \\
\hline & & NQF & NQF & NQF \\
\hline \multirow[t]{2}{*}{ Third year } & $\begin{array}{l}\text { New proposed staff nurse } \\
\text { (R.171)NQF } 6\end{array}$ & $\begin{array}{l}\text { Practice as a third-year } \\
\text { student }\end{array}$ & Practice as a third-year student & Practice as a third-year student \\
\hline & & NQF & NQF & NQF \\
\hline \multirow[t]{2}{*}{ Fourth year } & $\begin{array}{l}\text { Registered professional nurse } \\
\text { (RPN) (R.683) }\end{array}$ & $\begin{array}{l}\text { Practice as a fourth-year } \\
\text { student. }\end{array}$ & Practice as a fourth-year student. & $\begin{array}{l}\text { Practice as a fourth-year } \\
\text { student. }\end{array}$ \\
\hline & NQF 7 & NQF & NQF & NQF \\
\hline
\end{tabular}

Note: NQF = National Qualification Framework.

are not commensurate with their education and scope of practice, as prescribed by the applicable statutory body (Anderson, 2013).

The scope of practice can be defined as the actions or procedures that are permitted by law for a specific category of nurse to perform. The restrictions to what the law permits are based on the specific experience and educational qualifications of each category of nurse (Anderson, 2013; South African Nursing Council [SANC], 1991).

Nursing's scope of practice, defined for the various levels and cadres of nurses, exists specifically so as to understand the responsibilities and capabilities of each cadre and to render the best and most appropriate quality care to the patients. The level of accountability and responsibility of each cadre is encapsulated in the scope of practice. The primary concern for nurses should thus always be their ability to be a safe and proficient healthcare provider, practicing within a team of health professionals but still within the legal scope of their practice.

Efficient and quality patient care depends on teamwork. Interprofessional teamwork between the various categories of nurses is essential to quality nursing care. Nurses with limited scope of practice play an integral role in the delivery of health care, but they should not be responsible for or required to deliver care outside their scope of practice. Unfortunately, this practice sometimes occurs in countries where there is a critical shortage of registered nurses (Littlejohn, Campbell, Collins-McNeil, \& Khayile, 2012). In health care institutions where all cadres of nurses form the workforce, allocation of daily tasks is not always according to the specific scope of prac- tice (French, Du Plessis, \& Scrooby, 2011), and both the quality of patient care and the safety of the nurse are consequently at risk.

The South African nursing workforce consists of four broad categories of nurses (Table 1). Private nursing education institutions (NEIs) can offer nursing certificates (first 2 years of study) or a diploma (4 years of study). After completion of the first year of study, nurses (licensed or enrolled as auxiliary nurses) can perform basic nursing care. After completion of the second year of study (licensed or enrolled as enrolled nurses [ENs]), they can render more specialized basic nursing care. Third- and 4 th-year diploma students, registered students at nursing colleges (4-year integrated diploma or 2-year bridging course to registered nurse), universities of technology (4-year integrated diploma or degree), and universities (4-year integrated degree), can practice as student nurses and perform tasks under the scope of practice of the registered professional nurse, but under supervision, until completion of their qualifications.

Other countries around the globe may have other categories of nurses trained at various institutions (Table 2), but in principle, different cadres of nurses can legally perform different duties and tasks. Table 2 illustrates the authors' understanding of the different categories of nurses in South Africa, Australia, the United States, and the United Kingdom. Each category of nurse is essential for the nursing profession and responsible for quality basic patient care performed within their scope of practice and based on their specific education and the expected outcomes of their curricula. 
Table 2. Comparison of Nursing Categories

\begin{tabular}{|c|c|c|c|c|}
\hline & South Africa & Australia & United States & United Kingdom \\
\hline \multirow[t]{2}{*}{ Specialized } & Nursing specialist & Nurse practitioner (NP) & Advanced practice & \\
\hline & $\begin{array}{l}\text { Advanced nursing } \\
\text { practitioner (ANP) }\end{array}$ & $\begin{array}{l}\text { Specialization after basic } \\
\text { training }\end{array}$ & registered nurse (APRN) & \\
\hline \multirow[t]{4}{*}{ Top level } & $\begin{array}{l}\text { Professional registered } \\
\text { nurse (PRN) }\end{array}$ & Registered nurse (RN) & RN & RN (A-level) \\
\hline & $\begin{array}{l}\text { degree or diploma (4 years } \\
\text { of training) }\end{array}$ & $\begin{array}{l}\text { degree or diploma (3 years } \\
\text { of training) }\end{array}$ & degree (4 years of training) & $\begin{array}{l}\text { degree of } 3 \text { to } 4 \text { years, or } \\
\text { diploma of } 3 \text { years (3-4 } \\
\text { years of training) }\end{array}$ \\
\hline & Staff nurse & $\begin{array}{l}\text { Endorsed enrolled nurse } \\
\text { (EEN) }\end{array}$ & & \\
\hline & $\begin{array}{l}\text { College ( } 3 \text { years of } \\
\text { training) }\end{array}$ & & & \\
\hline \multirow[t]{2}{*}{ Intermediate level } & Enrolled nurse (EN) & EN & RN & RN (O-level) \\
\hline & $\begin{array}{l}\text { College certificate ( } 2 \text { years } \\
\text { of training) }\end{array}$ & $\begin{array}{l}\text { Diploma at college or } \\
\text { related health facilities } \\
\text { (1-2 years of training) }\end{array}$ & $\begin{array}{l}\text { Associate degree or } \\
\text { hospital diploma ( } 2 \\
\text { years of training) } \\
\text { licensed practical nurse } \\
\text { (LPN) or licensed } \\
\text { vocational nurse (LVN) } \\
\left(1 \frac{1}{2}-2 \text { years of training) }\right.\end{array}$ & $\begin{array}{l}\text { Hospital diploma ( } 2 \text { years } \\
\text { of training) EN } \\
\text { hospital-based training } \\
\text { (2 years of training) }\end{array}$ \\
\hline \multirow[t]{2}{*}{ Lower level } & $\begin{array}{l}\text { Enrolled nursing auxiliary } \\
\text { (ENA) or nursing } \\
\text { assistant certificate (1 } \\
\text { year of training) }\end{array}$ & $\begin{array}{l}\text { Assistant in nursing } \\
\text { Hospital-based training }\end{array}$ & $\begin{array}{l}\text { LPN Vocational or } \\
\text { technical school or } \\
\text { college (1 year of } \\
\text { training) }\end{array}$ & $\begin{array}{l}\text { Assistant in nursing } \\
\text { Hospital-based training } \\
\text { (6 weeks) }\end{array}$ \\
\hline & $\begin{array}{c}\text { Care workers Unlicensed } \\
\text { not regulated by SANC } \\
\text { (6 months of training) }\end{array}$ & $\begin{array}{l}\text { Assistant in nursing (AIN), } \\
\text { aged care worker } \\
\text { (ACW), personal care } \\
\text { assistant (PCA), care } \\
\text { support employee } \\
\text { (CSE), and health } \\
\text { services assistant (HSA) }\end{array}$ & $\begin{array}{l}\text { Unlicensed assistive } \\
\text { personnel }\end{array}$ & $\begin{array}{l}\text { Healthcare assistants } \\
\text { (sometimes known as } \\
\text { nursing auxiliaries or } \\
\text { support workers) }\end{array}$ \\
\hline Regulating body & SANC & $\begin{array}{l}\text { Australian Nursing Council } \\
\text { The Nursing and } \\
\text { Midwifery Board of } \\
\text { Australia }\end{array}$ & $\begin{array}{l}\text { National Council of State } \\
\text { Boards (each state has } \\
\text { its own regulating body) }\end{array}$ & $\begin{array}{l}\text { U.K. Central Council (each } \\
\text { state has its own } \\
\text { regulating body) }\end{array}$ \\
\hline
\end{tabular}

Note: SANC $=$ South African Nursing Council.

\section{Patient Assessment}

The nursing process, developed by Orlando in 1958, originally consisted of four generic consecutive but interwoven steps: assessment, planning, implementation, and evaluation (Magnan \& Maklebust, 2009; Nursingprocess.org, 2013). It is a conceptual framework that allows a systematic evaluation of a patient's current health status and needs (Huckabay, 2009). Patient assessment, as the first step in the sequence, forms the framework on which all individualized, patient-specific nursing care is planned. This assessment is based on sound scientific knowledge coupled with personal interpretation and very often intuition. Within the South African context, only professional registered nurses (PRNs) are allowed to perform patient assessments. Internationally it is expected that nurses having at least a 4-year university education should be responsible for patient assessment and nursing diagnosis. As illustrated in Table 2, this corresponds with the duties and responsibilities of the 3- or 4-year degree or diploma-qualified registered nurse who assumes a supervisory role in the clinical setting in the United Kingdom, United States, and Australia.

Therefore, assessment and planning of nursing care are the responsibility of the registered nurse in charge of patient care, while implementation of the care, on the other hand, can be performed by all cadres of nurses under the supervision of the registered nurse. If assessment is done incorrectly, it will ultimately influence the planning and therefore might hamper or negatively influence the quality of basic nursing care. It is therefore important that assessment, as described within the scope of practice, should be performed by those nurses adequately and comprehensively qualified, legally permitted, and 
responsible. The global nursing shortage might be one of the reasons why this very important responsibility is sometimes performed by a cadre of nurses not permitted or trained to do it. One type of risk assessment generally performed on hospitalized patients is pressure ulcer risk assessment, and it will be used in this article as a case to illustrate the risk to basic nursing care if it is performed by nurses not equipped or allowed to perform this duty.

\section{Pressure Ulcer Risk Assessment}

Pressure ulcers are costly for both the patient and the institution and should be avoided. Avoidable pressure ulcers occur when risk assessments, preventative actions, and continued reevaluations have not been implemented (Guy, 2012). However, pressure ulcers are still a common occurrence in healthcare institutions worldwide. Prevalence ranges are $10 \%$ to $17 \%$ in acute care, $0 \%$ to $29 \%$ in home care, and $2 \%$ to $28 \%$ in long-term care facilities (Ayello, 2007). The prevalence rate of pressure ulcers in the participatory healthcare institution prompted this study.

Different healthcare institutions have different policies on the assessment of a patient's health status needs. In the participating hospital group, the Waterlow ${ }^{\mathrm{TM}}$ (Judy Waterlow, The Nook, Stroke Road, Henlade, TAUNTON, TA3 5LX) scale has been adopted for risk assessment of pressure ulcers. This specific scale is widely used in the United Kingdom, Europe, and South Africa, but it is also frequently criticized for its low reliability (Kottner, Dassen \& Tannen, 2009). A part of the problem for this lack of inter-rater reliability is that nurses do not use the scale correctly (Kelly, 2005), so the interpretation is incorrect and patient care is affected. This may be due to nurses performing this very important duty outside their scope of practice and thus not being knowledgeable enough. The Waterlow ${ }^{\mathrm{TM}}$ scale measures risks taking into consideration the following aspects: build and weight, continence, skin type, mobility, sex (gender) and age, appetite, special risk, neurological deficits, major surgery and trauma, and medication (Waterlow, 2005). The critical factor in using the Waterlow ${ }^{\mathrm{TM}}$ scale is to do the scoring of the different risk aspects correctly, and in so doing make the interpretation of the result reliable. The nursing interventions, frequency, and quality of care provided will be based on the final score. Therefore, this action should be performed by a nurse with the necessary theoretical knowledge, critical thinking, and decision-making skills. These competencies are normally expected outcomes of nursing graduates (Kaddoura, 2010) and will be stated within their scope of practice.

\section{Methods}

\section{Design, Setting, and Sample}

A quantitative retrospective research design was used. The study was executed in a private hospital that forms part of one of the three largest private hospital groups in South Africa. A document review (patient file audit) was done in May 2012. Two PRNs, qualified as nurse educators, did the audit. The population consisted of 849 patient files and was limited to patients admitted during May 2012 only. A simple random probability sampling strategy was followed. One hundred and fifty-seven randomly selected patient files were evaluated according to a self-generated audit instrument. The audit instrument was developed from literature available on the Waterlow ${ }^{\mathrm{TM}}$ scale as a risk assessment tool. The audit was executed by correlating the data on the admission document, basic needs assessment tool, and progress report, with the score indicated on the Waterlow ${ }^{\mathrm{TM}}$ scale. A pilot study involving nurse managers and educators at another hospital was done to test the audit instrument. Files from pediatric patients, neonatal admissions, and maternity wards, as well as short-term admissions in surgical wards, were all excluded from the study because these patient files did not meet the criteria for the completion of the Waterlow ${ }^{\mathrm{TM}}$ scale.

\section{Ethical Considerations}

Before commencement of the study, the university's higher degrees committee approved the ethical standards of the research study. All ethical aspects were adhered to, and ethical clearance was given by the hospital group's ethical committee. Permission to retrieve files to be audited was granted by the specific hospital's management team. A confidentiality agreement was signed with the hospital management of that specific hospital. Only patient files of already discharged patients were audited. This was done under strict conditions of confidentiality. The data could not be linked back to a specific patient file. All sources were acknowledged to avoid any plagiarism.

\section{Data Analysis}

Data were processed using Microsoft Excel (Microsoft Corporation, Redmond, WA, USA). Scores were depicted in fractions and percentages in the form of graphs and tables. The results were double-checked by two senior faculty members of a local university.

\section{Results}

The Waterlow ${ }^{\mathrm{TM}}$ scale was completed in 152 (96.8\%) of the files that were audited, and 5 patient files 
revealed that no assessment using the Waterlow ${ }^{\mathrm{TM}}$ scale was done. Only 30 files (20\% of the Waterlow ${ }^{\mathrm{TM}}$ scoring) were audited by PRNs, $30(20 \%)$ by ENs, 46 (30\%) by the enrolled nursing auxiliary (ENAs), and 46 (30\%) by student nurses in training. Eighty-four (55.2\%) of the audited Waterlow ${ }^{\mathrm{TM}}$ scales were incorrectly scored or aspects were omitted. Only $20 \%$ of the Waterlow ${ }^{\mathrm{TM}}$ scales were completed by PRNs, with an $83 \%$ accuracy score. The areas that were most frequently scored incorrectly or omitted were neurological deficits, tissue malnutrition, medication, and weight or build.

\section{Discussion}

The implication of the results in the preceding section are that $80 \%$ of the Waterlow ${ }^{\mathrm{TM}}$ scales were completed by nurses who are either still in training or who acted outside their scope of practice. Inaccurate scores were therefore mostly calculated by nurses still in training or whose level of training and the expected outcomes of the curriculum do not include an in-depth assessment and theoretical knowledge of these complex factors. This inaccurate assessment might hinder timely intervention to prevent ulcer development in patients. Their scope of practice [R.2176: 6.1(F)] clearly indicates that the ENA "is able to assist with the implementation of nursing acts for individuals or groups as part of the nursing regimen planned by a registered nurse or registered midwife, with particular reference to basic human needs" (SANC, 1997a, p. 3). The scope of practice [R.2175: 6.1(G)] for the EN "is able to implement nursing acts for individuals or groups as part of the nursing regimen, planned by a registered nurse or registered midwife, with particular reference to basic human needs" (SANC, 1997b, p. 3). It is therefore not expected of these lower categories of nurses to be skilled “(b) ... in the diagnosing of individual, family, group and community health problems and in the planning and implementing of therapeutic action and nursing care for the health service consumers at any point along the health/illness continuum in all stages of the life cycle (including care of the dying), and evaluation thereof" (SANC, 1988, p. 2).

Likewise, the scope of practice of the EN corresponds with that of the licensed practical nurses (LPNs), who may render "supportive and restorative care under the direction of a registered professional nurse" but who "do not have assessment privileges" while functioning in a dependent role under the supervision of a registered nurse (NYSED.gov, 2013).

Interpretation of neurological deficits, tissue malnutrition, medication, and weight or build were the aspects most likely to be scored and interpreted incorrectly. Neurological deficits are a functional abnormality of a body area due to a decreased function of the brain, spinal cord, muscles, or nerves (Dugdale, 2013). The nurse responsible for assessment should therefore have the theoretical knowledge as well as capability to apply the knowledge to be able to allocate and interpret the correct score, ultimately preventing the development of pressure ulcers. The theoretical knowledge of lower cadres of nurses is inadequate due to the fact that it is not an expected outcome of their curricula. It is expected of them to apply basic knowledge of anatomy, physiology, and pharmacology when participating in the implementation of basic nursing care. Thus, they were not legally entitled to do the scoring, but the task was delegated to them. The PRN will be accountable and should ensure that the patient receives quality nursing care.

Medication knowledge is found to be unsatisfactory among many practicing nurses (Simonsen, Johansson, Daehlin, Osvik, \& Farup, 2011), supporting the rationale as to why lower cadres of nurses (such as ENAs and 1st-year students), like the $80 \%$ in this study who scored the risks pertaining to medication, should not have been expected to perform a patient assessment. To expect lower cadres of nurses to have enough insight and knowledge pertaining the effect of medication, as expected in the risk assessment tool, is unrealistic. Auxiliary and lower cadres of nurses should assist the registered nurse (Booysen, Erasmus, \& Van Zyl, 2012) and can implement the nursing care plan, but they cannot be expected to do the assessment. Wrong scoring has implications for the care plan and ultimately the quality of patient care. "Properly trained, experienced professional registered nurses should conduct pressure ulcer risk assessments" (Papanikolaou, Lyne, \& Anthony, 2007, p. 285) and other assessments to ensure quality patient care.

However, in the light of the current shortage of nurses, it might be argued that the scope of practice of the lower cadre of nurses should be extended (also known as task shifting) so that they can perform accurate assessments. To merely extend the scope of practice to legally protect the lower cadre of nurses will not solve the problem and has implications for quality patient care. The World Health Organization (2008) also confirms that task shifting alone is not the solution and is only a viable option if it is accompanied by expanded training and additional supervision (Ng'ang'a \& Woods Byrne, 2012). Patient assessment is not a task, but a skill and competency that are derived from sound theoretical knowledge, critical and analytical thinking skills, as well as the ability to integrate theory and practice (Kaddoura, 2010). The extension of a scope of practice will therefore ultimately have implications for the selection criteria of students because the previously mentioned competencies are generally expected from graduate nurses (Kaddoura, 2010), and 
in the African context, from 4-year degree or diploma nurses.

Accurate assessment improves the quality of patient care. It should be performed by professional nurses with sound theoretical knowledge, critical thinking skills, and the ability to integrate theory and practice.

\section{Study Limitations}

Although this study was conducted in only one large private hospital, the policies regarding nursing care are relatively standard throughout the hospital group, and one can assume that the same result will be found in other hospitals within the same group. However, generalization of the results cannot be assumed, and it is the recommendation that this study be repeated over a longer period of time and in more hospitals in the same private hospital group as well as in other hospitals, both public (state) and private.

\section{Recommendations}

In a hospital, the nursing practice is guided by both the scope of practice and the policies of the specific hospital or hospital group. Therefore, there might be a need to analyze these policies critically to determine whether there are specific limitations and guidelines as to who is responsible for certain nursing-related tasks, such as risk assessment of a patient. In-service (or continuous professional development) training might be needed to update and inform the registered nurses regarding the roles and responsibilities of the lower-category workers that he or she supervises, to prevent lower cadres of nurses from practicing outside their scope to the detriment of basic nursing care.

\section{Conclusions}

Correct patient assessment, by adequately prepared registered nurses, is critical to ensure optimal and quality care of patients. The patients trust the healthcare provider to be competent and knowledgeable and to ensure their safety and assist in their speedy recovery. When the initial assessment is incorrect, risks are not correctly identified and acted upon, which might impede patient care. In addition this could have various legal implications for the hospital and could involve liability for the specific nurse. This article emphasizes the importance of adhering to the legal scope of practice of the various nursing categories in order to abide by the "do not harm" principle that distinguishes the nursing profession and enhances quality nursing care of patients.

\section{Acknowledgments}

Thank you to our fieldworkers Haomi Hatting, Loraine Meyer, and Annalise Snyman who assisted in collecting the data.

\section{Clinical Resources}

- South African Nursing Council, www.sanc.co.za.

- Department of Health, The National Strategic Plan for Nurse Education, Training and Practice 2012/13-2016/17, http://www.doh.gov.za/docs/ stratdocs/2013/Strategic_Plan_for_Nurse_Education_ Training_and_Practice.pdf

- Broadening the Scope of Nursing Practice, http:// www.nejm.org/doi/full/10.1056/nejmp 1012121

- Scope of Practice and the Nurse Practitioner: Regulation, Competency, Expansion, and Evolution, http://www.oregon.gov/OSBN/pdfs/kleinmedscapearticle.pdf

- A trial of nurse practitioner scope of practice, http://onlinelibrary.wiley.com/doi/10.1111/j.13652648.2004.03273.x/full

\section{References}

Anderson, L. (2013). Understanding the different scope of nursing practice. NurseTogether.com. Retrieved from http://www. nursetogether.com/understanding-the-different-scope-ofnursin

Booysen, L., Erasmus, H., \& Van Zyl, M. (2012). The auxiliary nurse. Cape Town, South Africa: Juta.

Dugdale, D. (Ed.). (2013). Neurologic deficit. MedlinePlus medical encyclopedia. Retrieved from www.nlm.nih.gov/ medlineplus/ency/article/002267.htm?

Duncan, K. (2007). Preventing pressure ulcers: The goal is zero. Joint Commission Journal on Quality and Patient Safety, 33(10), 605-610.

Fero, L., Witsberger, C., Wesmiller, S., Zullo, T., \& Hoffman, L. (2008). Critical thinking ability of new graduate and experienced nurses. Journal of Advanced Nursing, 65(1), 139-148. doi:10.1111/j.1365-2648.2008.04834.x

French, H., Du Plessis, E., \& Scrooby, B. (2011). The emotional well-being of the nurse within the multi-skill setting. Health SA Gesondheid, 16(1). Retrieved from www. hsag.co.za/index.php/HSAG/article/view/553/609. doi:10.4102/hsag.16il.553

George, G., Quinlan, T., Reardon, C., \& Aguilera, J. (2012). Where are we short and who are we short of? A review of 
the human resources for health in South Africa. Health SA Gesondheid, 17(1), article 622. Retrieved from http:// www.hsag.co.za/index.php/HSAG/rt/printerFriendly/ $622 / 783$

Guy, H. (2012). Pressure ulcer risk assessment. Nursing Times, $108(4), 16-20$.

Huckabay, L. (2009). Clinical reasoned judgment and the nursing process. Nursing Forum, 44, 72-78. doi:10.1111/j.1744-6198.2009.00130.x

Kaddoura, M. (2010). New graduate nurses' perceptions of the effects of clinical simulation on their critical thinking, learning, and confidence. Journal of Continuing Education in Nursing, 41(11), 506-516. Retrieved from http://www.ncbi. nlm.nih.gov/pubmed/20672760.doi:10.3928/0022012420100701-02

Kelly, J. (2005). Inter-rater reliability and Waterlow's pressure ulcer risk assessment tool. Nursing Standard, 19(32), 86-92.

Kottner, J., Dassen, T., \& Tannen, A. (2009). Inter- and intrarater reliability of the Waterlow pressure sore risk scale: A systematic review. International Journal of Nursing Studies, 46(3), 369-379. doi:10.1016/j.ijnurstu. 2008.09.010

Littlejohn, L., Campbell, J., Collins-McNeil, J., \& Khayile, T. (2012). Nursing shortage: A comparative analysis. International Journal of Nursing, 1(1), 22-27. Retrieved from www.ijnonline.com/index.php/ijn/article/ download/21/pdf?

Magnan, M., \& Maklebust, J. (2009). The nursing process and pressure ulcer prevention: Making the connection. Advances in Skin $\theta$ Wound Care, 22(2), 83-92. doi:10.1097/01.ASW.0000345279.13156.d0

Ng'ang'a, N., \& Woods Byrne, M. (2012). Prioritizing professional practice models for nurses in low-income countries. Bulletin of the World Health Organization, 90(3), 3A. Retrieved from http://www.who.int/bulletin/volumes/ 90/1/11-097659/en/. doi:10.2471/BLT.11.097659

Nursingprocess.org. (2013). An in-depth look into the nursing process. Retrieved from www.nursingprocess.org/NursingProcess-Steps.html
NYSED.gov. (2013). The differentiated scope of practice of licensed practical nurses (LPNS) and registered professional nurses (RNs). Office of the Professions. Practice information. Retrieved from http://www.op.nysed.gov/prof/nurse/nurse-scopelpn-rn.htm

Papanikolaou, P., Lyne, P., \& Anthony, D. (2007). Risk assessment scales for pressure ulcers: A methodological review. International Journal of Nursing Studies, 44(2), 285-296.

Simonsen, B., Johansson, I., Daehlin, G., Osvik, L., \& Farup, P. (2011). Medication knowledge, certainty, and risk of errors in health care: A cross-sectional study. BMC Health Services Research, 11, 175. Retrieved from http://www. biomedcentral.com/1472--6963/11/175.doi:10.1186/14726963-11-175

South African Nursing Council. (1988). Regulations relating to the approval of and the minimum requirements for the education and training of a nurse (general, psychiatric and community) and midwife leading to registration. No. R.425 of February 22, 1985. Retrieved from http://www.sanc.co.za/regulat/Regscp.htm

South African Nursing Council. (1991). Regulations relating to the scope of practice of persons who are registered or enrolled under the Nursing Act, 1978. No. R.2598 of November 30, 1984. Retrieved from http://www.sanc.co.za/regulat/Regscp.htm

South African Nursing Council. (1997a). Regulations relating to the course leading to enrolment as a nurse. R.2175 of November 19, 1993. Retrieved from http://www.sanc.co.za/regulat/ Reg-scp.htm

South African Nursing Council. (1997b). Regulations relating to the course leading to enrolment as a nursing auxiliary. R.2176 of November 19, 1993. Retrieved from http://www.sanc.co. za/regulat/Reg-scp.htm

Waterlow, J. (2005). Pressure ulcer prevention manual (Revised). Retrieved from www.judy-waterlow.co.uk

World Health Organization. (2008). Task shifting: Global recommendations and guidelines. Treat, train, retain (TTR). Health Systems and Services. Retrieved from http://www. who.int/healthsystems/TTR-TaskShifting.pdf 